\title{
ARTIFICIAL AGGREGATE FROM SINTERED COAL ASH
}

\author{
UMETNI AGREGAT IZ SINTRANEGA PEPELA PREMOGA
}

\author{
Vit Cerny, Rostislav Drochytka \\ Brno University of Technology, Faculty of Civil Engineering, Veveri 95, 60200 Brno, Czech Republic \\ cerny.v@fce.vutbr.cz \\ Prejem rokopisa - received: 2015-07-22; sprejem za objavo - accepted for publication: 2015-09-23
}

doi: $10.17222 /$ mit.2015.235

\begin{abstract}
Fly ash is one of the most commonly used secondary raw materials in the Czech Republic. It is used predominantly for re-cultivation, roads and additions to cement or plasters. The use of fly ash in the technology of sintering-based artificial aggregate was tested in the 1980s. However, the production was stopped for various technological and economic reasons. Nowadays, possibilities for the production of artificial aggregate are tested with fly ash produced in the Czech Republic and could be promising for future technologies, mainly with respect to the stability of production. The paper presents part of the study describing the possibilities of using microsilica and $\mathrm{Fe}_{2} \mathrm{O}_{3}$ for the optimization of a raw-material mix and fly-ash body. Three samples of high-temperature lignite combustion fly ash were selected from prospective sources in the Czech Republic. The fly ash was mixed with $5 \%$ or $10 \%$ additions. Then, samples were fired at temperatures of $1150{ }^{\circ} \mathrm{C}$ and $1200{ }^{\circ} \mathrm{C}$. After firing, the physico-mechanical properties of the fly-ash bodies and microstructure were evaluated. The results imply that the addition of microsilica unambiguously improves the quality of the fly-ash body. The addition of $\mathrm{Fe}_{2} \mathrm{O}_{3}$ did not take part in the formation of the melt and weakened the fly-ash body's structure.
\end{abstract}

Keywords: fly ash, ash body, firing, microsilica, sintering, iron trioxide

Leteči pepel sodi k najpogosteje uporabljanim sekundarnim surovinam na Češkem. Predvsem se uporablja za rekultivacijo, za ceste in za cementne omete. Uporaba letečega pepela $v$ tehnologiji izdelave sintranih agregatov je bila preizkušena v osemdesetih letih prejšnjega stoletja. Vendar je bila proizvodnja ustavljena iz različnih tehnoloških in ekonomskih razlogov. Dandanes se preizkušajo možnosti za izdelavo umetnih agregatov iz letečega pepela nastalega na Ceškem, kar je lahko perspektivno za bodoče tehnologije, predvsem iz stališča stabilnosti izdelave. Članek predstavlja del študije o možnosti uporabe mikrosilike in $\mathrm{Fe}_{2} \mathrm{O}_{3}$ za optimizacijo mešanice surovin na osnovi letečega pepela. Trije vzorci letečega pepela pri visokotemperaturnem zgorevanju lignita, so bili izbrani iz obetavnih virov, ki so na voljo na Češkem. Leteči pepel je bil zmešan s $5 \%$ ali $10 \%$ dodatka. Nato so bili vzorci žgani pri temperaturi $1150{ }^{\circ} \mathrm{C}$ in $1200{ }^{\circ} \mathrm{C}$; po žganju so bile določene fizikalno-mehanske lastnosti teles iz letečega pepela in ocenjena je bila mikrostruktura. Rezultati kažejo, da dodatek mikrosilike nedvomno izboljša kvaliteto kosov iz letečega pepela. Dodatek $\mathrm{Fe}_{2} \mathrm{O}_{3}$ ni sodeloval pri nastanku taline in je oslabil zgradbo kosov letečega pepela.

Ključne besede: leteči pepel, kos letečega pepela, žganje, mikrosilika, sintranje, železov trioksid

\section{INTRODUCTION}

Power plants producing electrical energy create energetic by-products during the combustion of pulverized lignite. The dominant proportion of the by-products is fly ash. Ecological and economic reasons motivate technological innovations focusing on using solid waste. The production of artificial fly-ash aggregate is a suitable construction material, which could be made from fly ash. Artificial, sintered, fly-ash aggregate is one of the few construction materials that can be produced only with fly ash. European and worldwide trends of newly developed building technologies accentuate the demand for the production of high-quality, sintered, artificial, fly-ash aggregate. If the character of the fly ash is optimal, no further treatment is needed. However, not every sample of fly ash has an optimal composition. The quality of fly ash has an influence on the composition of the mix, the technological parameters and the quality of the produced aggregate. For enhancing the properties of sintered fly-ash aggregate, additions commonly used in the cera- mics industry could be used. The main candidates are microsilica and oxides of iron.

Microsilica is an amorphous $\mathrm{SiO}_{2}$, which is commonly obtained from separators during the production of ferrosilicon and silicium in electric arc furnaces. The application of microsilica in fire-resistant materials has been known for more than 40 years. The main task of microsilica in fire-resistant ceramic materials is the reaction in the system of binders, including the reaction mechanism at various temperatures. Various temperatures can be critical as regards the reactions. Microsilica consists of spheroidal particles with a mean diameter of around 0.15 microns. These spheroidal particles are a construction unit of primary agglomerates, which are bound to one another by strong bonds. The large specific surface and the wide distribution of microsilica increases the effectiveness of the encapsulation of the grains and the functionality of the fire-resistant ceramic materials compared to a narrow fraction. Microsilica is usually the finest part of the system with a specific surface of around $20 \mathrm{~m}^{2} \mathrm{~g}$. The surface properties and possible impurities are important for a determination of the properties of the 
final product. Microsilica can add more than $50 \%$ to the total surface area of the particles in the mix. ${ }^{1}$

Oxides of iron influence the formation of a ceramic body in various atmospheres ${ }^{2}$, temperatures and firing cycles in furnaces There are three main forms of iron used in ceramics: red iron trioxide $\left(\mathrm{Fe}_{2} \mathrm{O}_{3}\right)$, black iron monoxide oxide or magnetite $\left(\mathrm{FeO}\right.$ or $\left.\mathrm{Fe}_{3} \mathrm{O}_{4}\right)$ and yellow hydrated iron oxide $(\mathrm{FeO}(\mathrm{OH}))$. Iron trioxide is considerably influenced by a reducing atmosphere, in which it can act as a melting agent at high temperatures. The presence of iron reduces the temperature of melting. ${ }^{3}$ From the point of view of a reduction of the firing temperature, oxides of iron can be used as effective melting agents for the production of sintered fly-ash aggregate.

The optimal mix of appropriate raw materials for the production of artificial aggregate is mixed with water and granulated on a cylindrical or plate granulator, which makes the appropriate shape of the sintered fly-ash aggregate. After granulation, the bodies are fired at a maximum temperature of around $1200{ }^{\circ} \mathrm{C}$. After sufficient firing and cooling, the mix is crushed and screened for the final fractions.

For the production of aggregate of good quality, the granulometry of the input materials, their structure and chemical composition are also important. The produced sintered fly-ash aggregate is used for filtration layers, back filling and lightweight concrete. ${ }^{4-6}$

\section{EXPERIMENTAL PART}

Three samples representing prospective sources in the Czech Republic were selected for verification of the appropriateness of high-temperature lignite combustion fly ash for the production of artificial aggregate.

From the physico-mechanical and physico-chemical parameters we selected the loss on ignition (CSN 72 0103) showing unburned residues, the bulk density (CSN 72 2071), the specific surface area and the rest on the 0.045-mm sieve (CSN 72 2072-6). We also conducted the chemical and mineralogical analyses.

The parameters listed in Table $\mathbf{1}$ imply that fly ash produced in the Czech Republic has a minimal unburnt content and fulfills the requirements of the standard (CSN 72 2072-6, 2013) for a maximum loss on ignition of $15 \%$. For self-firing, it will be necessary to mix the fly ash with pulverized coal to achieve an optimal value of $8 \%$ combustibles by weight. The greater coarseness of the fly ash FA3 evaluated with respect to the rest on the $0.0045-\mathrm{mm}$ sieve and specific surface is evident. This fly ash also has a larger content of iron and lime, which can cause a reduction of the melting temperature of a batch. All the values of the high-temperature fly-ash samples fulfill the requirements of the Standard CSN 72 2072-6, 2013 for a minimal value of $800 \mathrm{~kg} \mathrm{~m}^{-3}$.

As is clear from Table 2 FA1 has the highest percentage of mullite and a lower content of amorphous phase in comparison with FA2 and FA3. The mineralogical analysis further confirms that FA2 contains more minerals with a lower melting point and a low content of mullite.

Table 2: Mineralogy of tested ashes, in mass fractions $(w / \%)$

Tabela 2: Mineralogija preizkušenih pepelov, $\mathrm{v}$ masnih odstotkih $(w / \%)$

\begin{tabular}{|c|c|c|c|c|c|}
\hline \multirow{2}{*}{ Sample } & Quartz & Mullite & Hematite & Magnetite & $\begin{array}{c}\text { Amorphous } \\
\text { phase }\end{array}$ \\
\cline { 2 - 6 } & $\mathrm{SiO}_{2}$ & $\mathrm{Al}_{6} \mathrm{Si}_{2} \mathrm{O}_{13}$ & $\mathrm{Fe}_{2} \mathrm{O}_{3}$ & $\mathrm{Fe}_{3} \mathrm{O}_{4}$ & - \\
\hline FA1 & 7.0 & 39.3 & 1.2 & 0.1 & 39.5 \\
\hline FA2 & 7.2 & 19.1 & 2.5 & 3.1 & 55.2 \\
\hline FA3 & 7.8 & 32.3 & - & 0.2 & 58.1 \\
\hline
\end{tabular}

As an addition for the experimental work, microsilica $\left(96 \% \mathrm{SiO}_{2}\right.$ ) and $\mathrm{Fe}_{2} \mathrm{O}_{3}$ (powder, $97 \%$ cleanliness) were selected. As a reference, samples from pure fly ash were used, which were then modified with a $5 \%$ or $10 \%$ addition. The mixtures were mixed with water to reach the limit of fluidity. Samples of size $20 \mathrm{~mm} \times 20 \mathrm{~mm} \times$ $100 \mathrm{~mm}$ were made, which were next day dried at $60{ }^{\circ} \mathrm{C}$ for $2 \mathrm{~h}$ and then fired in a muffle kiln. The firing was characterized by an initial temperature of $25^{\circ} \mathrm{C}$ and the rate of firing the muffle kiln of $300{ }^{\circ} \mathrm{C} / \mathrm{h}$ and an isothermal dwell at $1150{ }^{\circ} \mathrm{C}$ (resp. $1200{ }^{\circ} \mathrm{C}$ ) for $10 \mathrm{~min}$. After firing and natural cooling, the specimens were taken out of the kiln and placed in a desiccator. After thermal stabilization, their density (CSN EN 1015-10), compressive strength (CSN EN 14617-15) and water-absorbing capacity (CSN EN 1097-6) were determined. Then, the samples were analyzed with a scanning electron microscope using a sensing element in an environmental form. Primarily, the structure was analyzed and the influence of the addition on the fly ash body.

\section{RESULTS AND DISCUSSION}

After firing in a laboratory furnace and sufficient cooling to laboratory temperature $20 \pm 5^{\circ} \mathrm{C}$, the following

Table 1: Main parameters of the tested ashes

Tabela 1: Glavni parametri preizkušenih pepelov

\begin{tabular}{|c|c|c|c|c|c|c|c|c|c|}
\hline \multirow{2}{*}{ Sample } & \multirow{2}{*}{$\begin{array}{c}\text { Loss on } \\
\text { ignition } \\
(\%)\end{array}$} & \multirow{2}{*}{$\begin{array}{c}\text { Bulk density } \\
(\text { compacted) } \\
\left(\mathrm{kg} / \mathrm{m}^{3}\right)\end{array}$} & \multirow{2}{*}{$\begin{array}{c}\text { Rest on the sieve } \\
0.045 \mathrm{~mm} \\
(\%)\end{array}$} & \multirow{2}{*}{$\begin{array}{l}\text { Specific } \\
\text { surface } \\
\left(\mathrm{m}^{2} / \mathrm{kg}\right)\end{array}$} & \multicolumn{5}{|c|}{ Chemical composition (\%) } \\
\hline & & & & & $\mathrm{SiO}_{2}$ & $\mathrm{Al}_{2} \mathrm{O}_{3}$ & $\mathrm{Fe}_{2} \mathrm{O}_{3}$ & $\mathrm{SO}_{3}$ & $\mathrm{CaO}$ \\
\hline FA1 & 1.19 & 990 & 58.5 & 329 & 47.7 & 28.2 & 5.6 & 0.13 & 1.1 \\
\hline FA2 & 1.15 & 1010 & 72.0 & 234 & 50.0 & 23.4 & 14.5 & 0.26 & 3.4 \\
\hline FA3 & 1.07 & 1110 & 53.1 & 299 & 54.6 & 29.5 & 5.5 & 0.10 & 1.8 \\
\hline
\end{tabular}




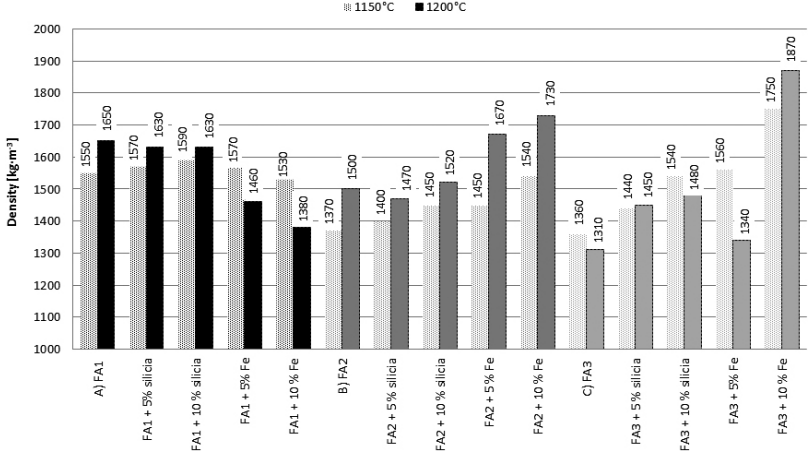

Figure 1: Density of fired samples

Slika 1: Gostota žganih vzorcev

physico-mechanical parameters of the test specimens were determined.

Figure 1 shows the results of the determination of density. In general, it can be stated that the density grows slightly with an increasing temperature of firing. The samples based on FA1 showed the highest values of density, while the samples based on FA3 showed the lowest density.

A determination of the compressive strength (Figure 2) showed that the strengths at the firing temperature $1200{ }^{\circ} \mathrm{C}$ were considerably higher than the strengths at $1150{ }^{\circ} \mathrm{C}$. The addition of silica had a very positive effect on the strength of the fly ash body - samples with as little as $5 \%$ showed considerably higher strengths. In contrast, the addition of $\mathrm{Fe}_{2} \mathrm{O}_{3}$ weakened the fly-ash body and the measured strengths were often lower than those of the reference samples based on pure fly ash.

An evaluation of the results of the determination of the water-absorbing capacity (Figure 3) in some cases shows the influence of firing temperature on the quality of the fly-ash body. The water-absorbing capacity of the samples fired at $1150{ }^{\circ} \mathrm{C}$ was often much higher. This can be caused by insufficient sintering of the fly-ash body and a higher proportion of open porosity. The influence of the type of addition on the results of the water-absorbing capacity is most marked for the samples based on FA with the addition of $\mathrm{Fe}_{2} \mathrm{O}_{3}$.

To clarify the results determined during the evaluation of the physico-mechanical parameters, the samples

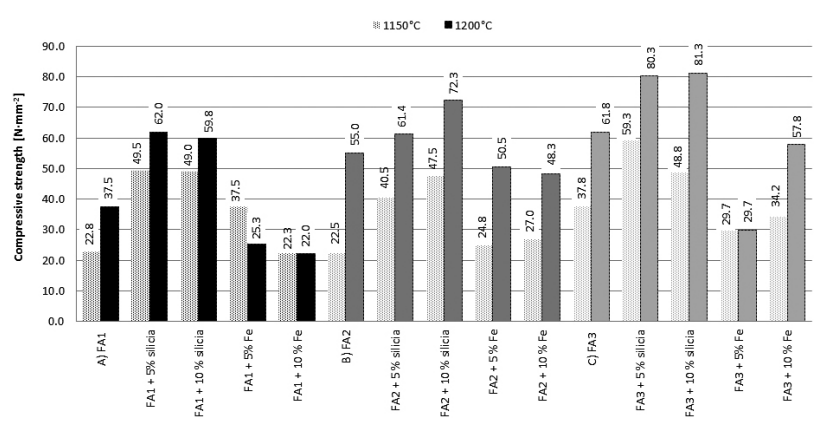

Figure 2: Compressive strength of fired samples Slika 2: Tlačna trdnost žganih vzorcev

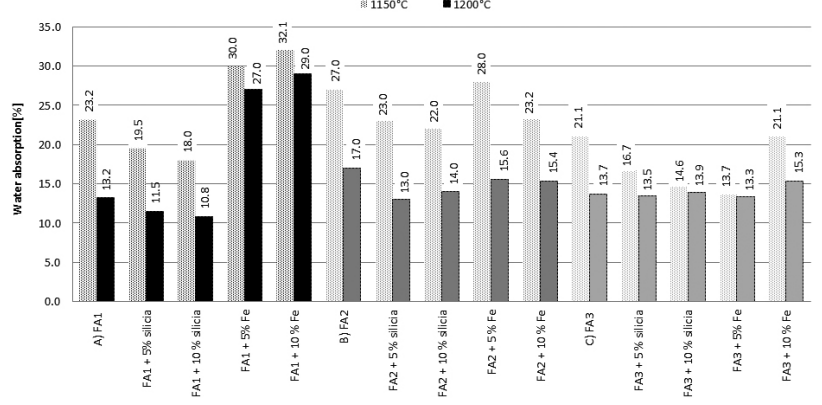

Figure 3: Water absorption of fired samples

Slika 3: Absorpcija vode žganih vzorcev

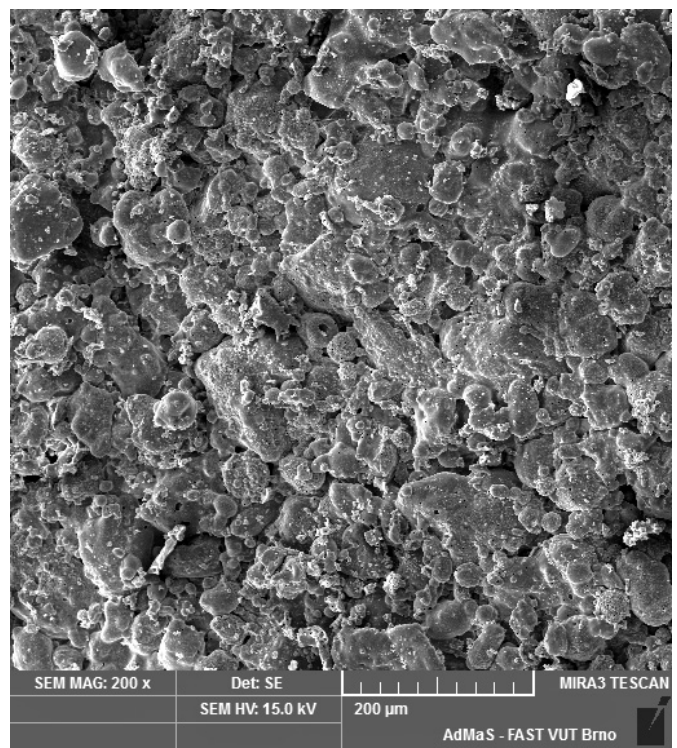

Figure 4: Structure of fly-ash body with $5 \%$ of mass fractions of $\mathrm{Fe}_{2} \mathrm{O}_{3}$

Slika 4: Struktura kosa letečega pepela s $5 \%$ masnega deleža $\mathrm{Fe}_{2} \mathrm{O}_{3}$

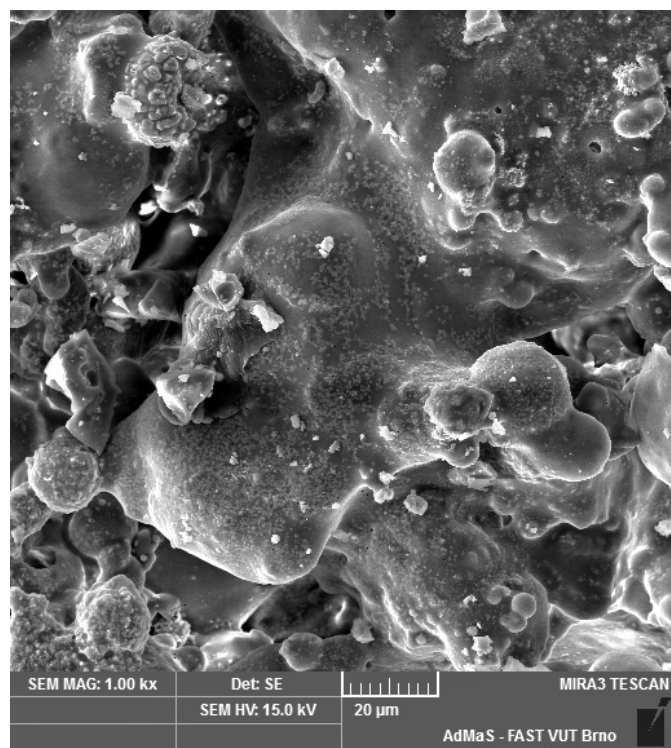

Figure 5: Detail of structure of fly-ash body with $5 \%$ of mass fractions of $\mathrm{Fe}_{2} \mathrm{O}_{3}$

Slika 5: Detaj1 strukture kosa letečega pepela s $5 \%$ masnega deleža $\mathrm{Fe}_{2} \mathrm{O}_{3}$ 


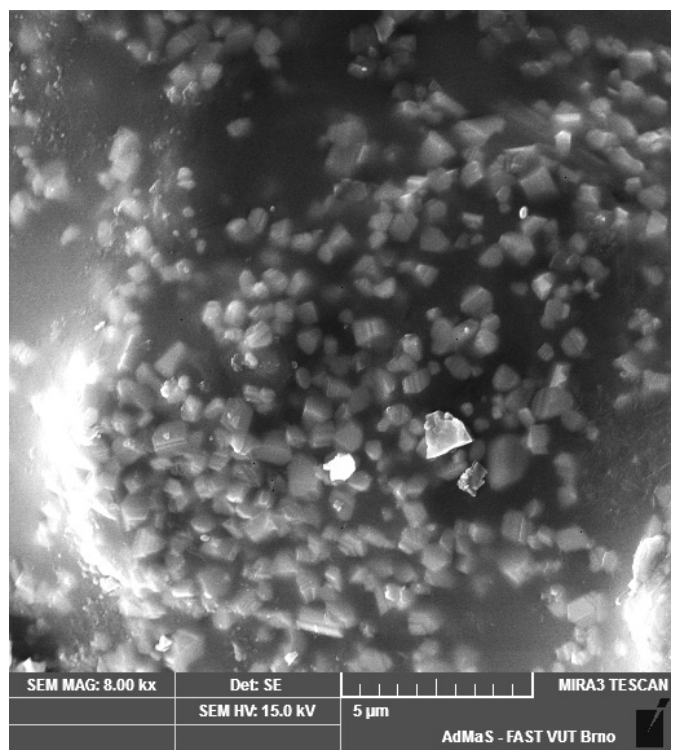

Figure 6: Non-reacted proportion of $\mathrm{Fe}_{2} \mathrm{O}_{3}$ in fly-ash body Slika 6: Nereagiran delež $\mathrm{Fe}_{2} \mathrm{O}_{3}$ v kosu letečega pepela

were examined under a scanning electron microscope with a sensing element in an environmental form. The aim was an evaluation of the influence of firing temperature and additions on the structure of the fly-ash body.

Figures 4 to 7 show the structure of a surface of a test specimen based on FA3 with a $5 \%$ addition of $\mathrm{Fe}_{2} \mathrm{O}_{3}$ and fired at $1200{ }^{\circ} \mathrm{C}$. Figure 4 shows a low proportion of sintered structure and visible grains of fly ash. Figure $\mathbf{5}$ shows a part of a sample with melted material at higher magnification, where non-reacted grains of $\mathrm{Fe}_{2} \mathrm{O}_{3}$ are visible. Figure 6 shows a closer detail of the same place grains of $\mathrm{Fe}_{2} \mathrm{O}_{3}$ and Figure 7 an analysis of the elements

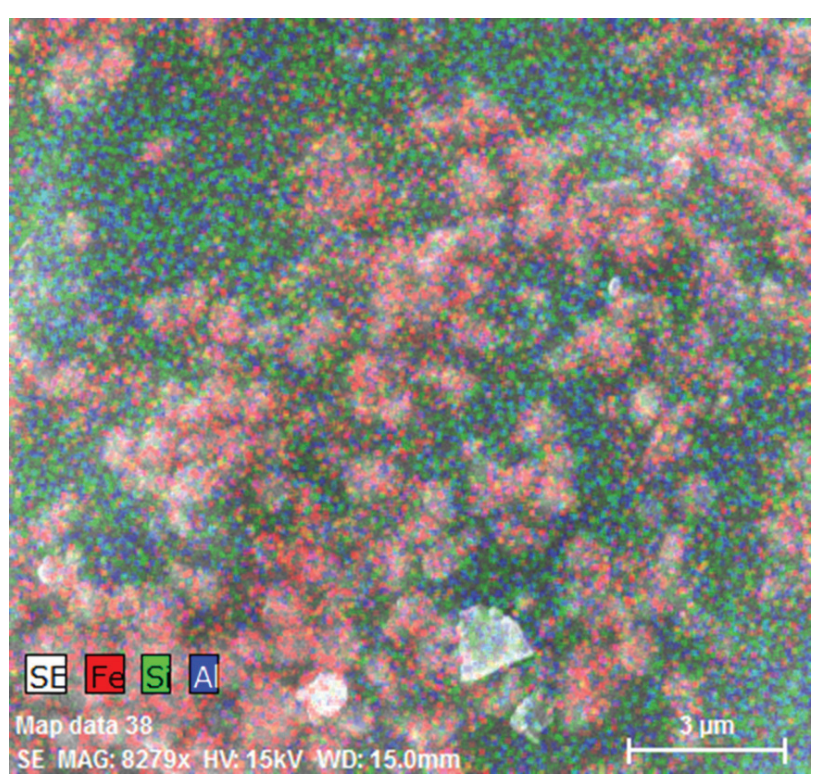

Figure 7: Marked composition of elements of sample with nonreacted $\mathrm{Fe}_{2} \mathrm{O}_{3}$

Slika 7: Razporeditev elementov v vzorcu, ki ni reagiral z $\mathrm{Fe}_{2} \mathrm{O}_{3}$

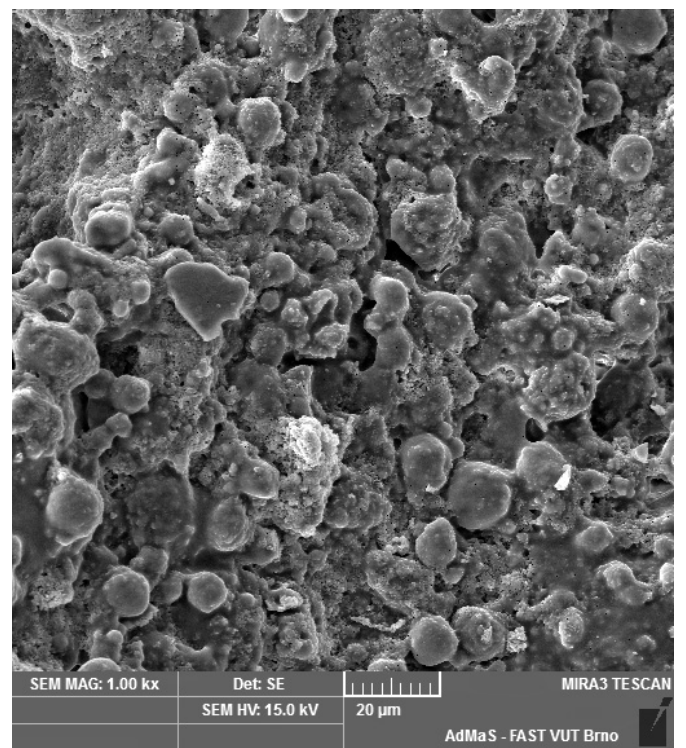

Figure 8: Structure of fly-ash body with $10 \%$ of mass fractions of silica

Slika 8: Struktura kosa letečega pepela z $10 \%$ masnega deleža kremena

in a larger area where the dominant $\mathrm{Fe}$ is evident in the grains. This fact proves that $\mathrm{Fe}_{2} \mathrm{O}_{3}$ did not take part in the formation of a solid structure, and that it weakened the fly-ash body.

Figures 8 and 9 show the structure of the test specimens based on FA3 with a $10 \%$ addition of silica. Figure 8 shows a sample fired at $1150{ }^{\circ} \mathrm{C}$, where the grains of fly ash and a minimal proportion of melted material are clear. Figure 9 shows a sample fired at $1200{ }^{\circ} \mathrm{C}$, where the proportion of melted material is more con-

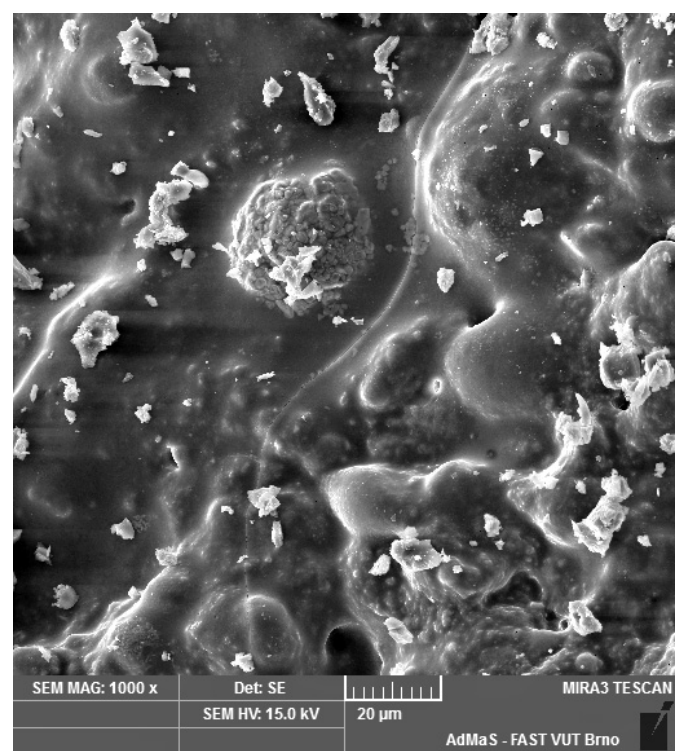

Figure 9: Detail of structure of fly-ash body with $5 \%$ of mass fractions of silica

Slika 9: Detajl strukture kosa letečega pepela s $5 \%$ masnega deleža kremena 
siderable and the grains have a stronger and more homogeneous structure.

\section{CONCLUSIONS}

The manufacture of artificial aggregate from fly ash is one of the options for using the maximum proportion of this raw material in construction materials. The character of the fly ash and good control of the technology for producing the aggregate by self-firing also brings savings for traditional raw materials. The paper described the experimental testing of possibilities for the modification of fly ash with the addition of microsilica or $\mathrm{Fe}_{2} \mathrm{O}_{3}$ in order to achieve better quality of the fly-ash body with a lower energy demand of the process. The results show how important it is to set the firing temperature at $1200{ }^{\circ} \mathrm{C}$, which makes sure it is possible to achieve considerably higher strengths in the system. An evaluation of the influence of the used additions showed that the addition of microsilica unambiguously improves the quality of the fly-ash body. Higher strengths and a lower water-absorbing capacity were achieved compared to use of pure fly ash. The addition of $\mathrm{Fe}_{2} \mathrm{O}_{3}$ did not take part in the formation of the melt, and stayed almost unchanged and weakened the fly-ash body structure.

\section{Acknowledgements}

This paper has been worked out under the project No. LO1408 "AdMaS UP - Advanced Materials, Structures and Technologies", supported by Ministry of Education, Youth and Sports under the "National Sustainability Programme I".

\section{REFERENCES}

${ }^{1}$ B. Sandberg, B. Myhre, Microsilica A Versatile Refractory Raw Material, Indian Refractories Congress, Jamshedpur, India 1994, 1-7

${ }^{2}$ R. Magrla, M. Fridrichova, K. Kulisek, K. Dvorak, O. Hoffmann, Utilisation of Fluidised Fly Ash for Reduction of $\mathrm{CO}_{2}$ Emissions at Portland Cement Production, Advanced Materials Research, 1054 (2014), 168-171, doi:10.4028/www.scientific.net/AMR.1054.168

${ }^{3} \mathrm{~J}$. Britt, All about iron: Iron is everywhere in many different forms, but that doesn't mean it has to be boring-or even brown, Cmtechnofileiron, 2011

${ }^{4} \mathrm{~J}$. Brozovsky, Influence of Moisture of Light-Weight Concrete Containing Lightweight Expanded Clay Aggregate on Test Results Obtained by Means of Impact Hammer, Advanced Materials Research, 753-755 (2013), 663-667, doi:10.4028/www.scientific.net/AMR. 753-755.663

${ }^{5}$ B. Yun, I. Ratiyah, P. A. M. Basheer, Properties of lightweight concrete manufactured with fly ash, furnace bottom ash, and Lytag, International Workshop on Sustainable Development and Concrete Technology, Beijing 2004, 77-88

${ }^{6}$ T. Melichar, J. Bydzovský, Study of the parameters of lightweight polymer-cement repair mortars exposed to high temperatures, Applied Mechanics and Materials, 395 (2013) 8, 429-432, doi:10.4028/www.scientific.net/AMM.395-396.429

${ }^{7}$ R. Sokolar, Keramika, Publishing house VUTIUM, Brno, Czech Republic 2006 